\title{
Grammar: How not to be Part of the Problem
}

\author{
Todd Hull* \\ Assistant Professor, Department of English, Hankuk University of Foreign Studies, Seoul, South Korea \\ *Corresponding Author: Todd Hull, Assistant Professor, Department of English, Hankuk University of \\ Foreign Studies, Seoul, South Korea
}

\begin{abstract}
Most of the literature about grammar in the EFL classroom concerns what if any role the presentation of grammar has in foreign language instruction. Opinions range from support for grammarbased curricula to those which include some focus on form to those who see no role at all for the explicit teaching of grammar. But one issue that is less discussed in relation to the everyday workings of the EFL classroom is the validity of purported grammar rules themselves, rules which teachers use as the standard for what is considered grammatically correct expression in their classrooms. This paper will discuss how many of the purported rules that underpin curricula around the world are specious and lead educators to use standards both in their teaching and testing which are not based on historically accurate data for assessing grammatical correctness. This can lead teachers to become part of the problem rather than the solution. What native speakers actually do-not what pseudo-grammarians think they should do-is the standard of grammatical correctness that should inform the EFL classroom. This paper reaffirms that language change is natural and should not be rejected, countering the position that the language of the EFL classroom remain static. Instead, language dynamism should be integrated into foreign language instruction.
\end{abstract}

Keywords: Grammar; English Grammar; Teaching Grammar; Focus on Form; Historical Grammar; Prescriptive Grammar; Descriptive Grammar; Language Testing; Language Use; Language Usage

\section{INTRODUCTION}

Correct grammar. In the eyes of many students studying foreign languages as well as a large constituent of laypeople like parents and even many in the educational bureaucracy such as principals and government administrators, that is the goal, and even the sum total, of studying another language. Scholars in the field of language acquisition on the other hand know that grammar is only a small part of language competence. The classic description of language competence comes from Canale and Swain (1980). In their formation, grammatical competence is only one out of four aspects, the other three being discourse, sociolinguistic, and strategic competencies. The other classic rubric of communicative competence was presented by Lyle Bachman (1990) who divided it into two major categories of organizational and pragmatic competence and subcategories of grammatical, textual, illocutionary, and sociolinguistic competence. So, contrary to lay opinion, there is much more to language competence than grammatical accuracy.

Nevertheless, grammar is something which is part of the EFL classroom. But what about its role? Should it be explicitly taught? Opinions span a wide range. At one end of the spectrum are curricula that are designed around the idea that grammar should be the skeleton of instruction that is then fleshed out by other aspects of language such as discourse competence. Others see a place for grammar, but only as a supplement more communicative teaching. Celce-Murcia (2003) and Nation (2001) assert that some explicit focus on form is beneficial to learners. But they stress that it has to be in the context of communicative teaching. Students actually need to be engaging in real communication with the language forms they have been focusing on. Rod Ellis $(2003,2005)$ is wellknown for his "consciousness-raising" tasks in which learners are given language and must figure out a specific grammar point from the language presented. They are then given the rule by the instructor. And finally, they practice in communicative context the grammar their consciousness has been raised about.

At the other end of the spectrum are educators who see no (or a very minimal) role for the explicit teaching of grammar. Steven Krashen (1982) is a long-time advocate of purely naturalistic learning 
where students are presented with an abundance of comprehensible input but receive little or no explicit focus on form. Krashen asserts that in this way students will gradually acquire the necessary building blocks of communication in the target language and start using it when they are comfortable doing so, without being asked to master specific forms or produce language before they feel comfortable doing so. Also in that school is Manfred Pienemann, who has put forth what he calls processability theory, which says that there is a set order of language point acquisition. He further asserts that explicit focus on form is actually detrimental to language acquisition, or at least counterproductive. (Pienemann 1989, 2012 and Pienemann, and Lenzing 2015). To give tools to educators wishing to move away from grammar-based curricula, Lightbown and Spada (2013) propose a number of practical ways that Pienemann's theories can work in actual classrooms.

\section{What is Correct Grammar? Who Makes Grammar ERrors?}

Whatever their position on the role of grammar in the EFL classroom, educators must have standards of what correct grammar is. And one issue about which there is a good amount of scholarship in the field of academic linguistics, but which is less discussed in the literature about what actually happens in everyday EFL classrooms is the validity of purported grammar rules themselves, rules that ultimately comprise the standard for what is considered grammatically correct speech for students studying English as a foreign language. The main purpose of this paper is to discuss in the context of how classroom teachers view grammatical correctness fallacies surrounding what is purported to be "correct" grammar and suggest ways that instructors can be part of the solution rather than the problem when it comes to what constitutes correct speech by having have an informed perspective on grammar that guides them in their own classroom instruction.

For scholars of language, an utterly uncontroversial statement is: Native speakers do not make grammar errors in their own language (with native speaker being defined as a cognitively normal, adult native speaker). It just does not happen. Native speakers make slips of the tongue, but not grammar errors. So what is correct grammar? Simply, correct grammar is what comes naturally out of the mouths of cognitively normal, adult native speakers of a language (more on the issue of who is a native speaker later). Who makes grammar errors? Native speaker children under the age of about six, non-native speakers of a language, and those with abnormal cognitive function.

Linguist, John McWhorter sums up divide between the layperson's conception of "correct grammar" and that of linguists, and the frustration in the academic community about the pervasive misperception that native speakers make grammar errors when using their own language: "One of the most frustrating things for any linguist is a virtually universal misimpression that the world is full of people [making grammar errors in their native languages, one of the] myths about language dismissed by all linguists, but [believed by] almost everyone else." (McWhorter 1998) Indeed, as soon as I tell native speakers of English that I meet for the first time what I do, one of the most common first comments I get is, "Oh, my grammar is terrible." My response, much to their surprise, is, "No. Since about the age of five or six, every time you've opened your mouth and English has come out, it has been $100 \%$ grammatically correct." It is lamentable but understandable to encounter this misperception amongst people who do not work with language professionally. But it is truly lamentable to meet English educators who still believe that native speakers can make grammar errors in their own language. Most depressing of all is the occasional English instructor who says that their own grammar is not always correct. It is these misconceptions that this paper seeks to confront.

\section{DeSCRIPTIVE Vs. PRESCRIPTIVE Grammar}

The classic description of the division between laypeople who fulminate against supposed "errors" made by native speakers and scholars of language who know that native speakers do not make grammar errors in their own language is the distinction between prescriptive and descriptive grammar. This is succinctly described by Steven Pinker (2014) who says that descriptivists are usually portrayed as those who "describe how language actually is used rather than prescribing how it ought to be used." Hitchings (2011) states that "a prescriptivist dictates how people should speak and write, whereas a descriptivist avoids passing judgements and provides explanation and analysis." A somewhat more forceful description of prescriptivism, and one which is in keeping with the stance of this paper, is given by Aitchison (2013), who defines prescriptive grammar as "any grammar which lays down artificial rules to impose some arbitrary standard of "correctness." Perhaps the best description of the prescriptivist project is given just by the title of former New York Times Book 
Review editor, Patricia O'Connor's book: Origins of the Specious: Myths and Misconceptions of the English Language. (O'Connor 2010) Finally, Davies and Langer (2006) show that in modern times prescriptivism is not just limited to English, but manifests itself in "purists" pontificating about other languages as well.

\section{Language Change}

A parallel aspect of prescriptivism is an adversarial stance towards language change, since many of the grammar "rules" propagated in classrooms across the world manifest themselves in the insistence on language forms of the past that English has moved on from. McWhorter (2011) states that "language is always changing - not just in words replacing one another...but in the grammar itself changing," an idea he later devotes a whole book to, in which he states, "It is not a question of whether a word will undergo... these processes [of lexical change], but which ones of them it will go through. (McWhorter 2017, emphasis in original). Likewise, David Crystal (2007) states that "...as people, and their societies, never stand still, neither do words." And in a jab at pundits, "Life and language have moved on, but people still worry." (Crystal 2006) O'Connor (2010) sees the idea of an immutable English for what it is: "Perhaps the biggest myth of all is that English never changes." Like McWhorter and the community of professional linguists, she makes it clear that language change is not just a lamentable fact that we have to simply accept but something which continually revitalizes the language. "Its ability to renew itself is what has kept English alive and kicking." Language vitality is maintained because of - not in spite of-language change. But prescriptivists resist it with all their energies. Crystal (2004) notes that, ironically, each generation of prescriptivists condemns the prescriptions of earlier prescriptivists, musing that "what puzzles me is why people fail to make the appropriate deduction from this behaviour, and see the pointlessness and counter-productiveness of being prescriptive about language."

\section{Descriptive and Prescriptive Grammar are not Mutually ExClusive}

Pinker, though, plausibly resolves the dichotomy between prescriptivism and descriptivism by honoring the speech of everyday native speakers, giving speech a wide latitude for what is considered grammatical. But he awards the status of careful and effective writers only to those who conform in their writing to many if not most of the prescriptivist dictates that he and other professional linguists do not apply to colloquial spoken language. In other words, the supposed grammar issues prescriptivists issue regular condemnations about are actually matters of style. What are called "errors" by the grammatical laity are actually utterances that either would not be part of a carefully styled piece of academic or journalistic prose or formal speech or are nothing but the personal pet peeves of self-appointed grammar experts who are in actuality anything but.

For actual scholars of language utterances like, "Ain't no beer up in the fridge" and "He don't got no money," condemned as "errors" by the grammatical laity, are not only utterly grammatical but utterly unexceptional, and pass without comment from linguists, except perhaps on their colloquial nature. Modern day prescriptivists also do not accept as standard African American English whereas scholars of language not only see it as a valid dialect, but seek "to inform and to challenge misconceptions, stereotypes, and prejudices associated with AAL" (Wolfram, \& Waldorf 2019) and show that Black English contains a number of complexities not extant in standard English (McWhorter 2017).

But language like that in the above examples about beer and money does not as often manifest itself in the EFL classroom as examples from more standard English. This paper will focus on the bogus rules which are not only wrongly used to denigrate native speakers in informal speech but that also A fourth class of rules that pervades EFL classrooms, with deleterious results for learners. At the same time, it will maintain Pinker's stance that careful writers of formal language should indeed adhere to a set of stylistic conventions that do not apply to informal communication.

\section{EXAMPLES OF ARTIFICIAL GRAMMAR "RULES"}

I will now give a few examples of myths, misconceptions, and artificial rules which implicitly or explicitly pervade EFL classrooms across the world and, more perniciously, appear on tests of English proficiency on which students must provide answers which are only "correct" according to fake grammar "rules" handed down by generations of prescriptivists. The answers students give on these tests can affect their future educational and job opportunities. 
A great number of these prescriptions were created in what I call the prescriptivist craze of the seventeenth, eighteenth, and nineteenth centuries, both in Britain and its overseas colonies. I (arbitrarily and subjectively) date the start of the prescriptivist era to a 1672 essay (cited in Bohn 1907) by the poet, John Dryden, called "Defence of the Epiloge" in which he castigated Shakespeare for supposed errors the Bard had made in his poems and plays - perhaps the fulminations of a lesser figure covetous of his predecessor's fame. Prescriptivists had of course been around for a long time before Dryden's essay, but things really took off around the time he published it. In particular, they accelerated amongst figures with no specific education or training in historical linguistics, philology, as it was called at the time. "The most important eighteenth century development in the English language was its conscious regulation by those who were not really qualified for the job but who managed to acquire authority as linguistic gurus." (Algeo \& Butcher 2013)

One class of false grammar rules bogusly created out of whole cloth was that of pseudo-historical claims about the history of English. One example of this is asserting that utterances like "It is her" should be "It is she." Pseudo-scholars said that English came from Latin and since in Latin the nominative case rather than the objective (accusative) case must follow the copula, so must it in English. The biggest problem for this claim is that English, of course, did not "come from" Latin. English and Latin are both Indo-European languages, but English is of the West Germanic branch, which definitely did not "come from" Latin and is under no obligation to conform to Latin Grammar. But even if it did "come from" Latin, should it strictly follow the rules of another language when it is its own language? No.

Another category was supposed "illogical" constructions that were deemed grammatically incorrect because they did not, in the eyes of prescriptivists, make logical sense. Excoriation of the double negative falls into this category. Pseudo-grammarians said that it was logically impossible for the double negative to have a negative meaning in English. The reasoning here was that in math a double negative equals a positive, so too must it in English. But of course language and math are entities following utterly different sets of principles. Not only are double negatives used as negatives in a great number of world languages with no befuddlement amongst the ranks of their speakers, but in the past they had been used for hundreds of years in English as negatives with no confusion or condemnation. This is another bogus rule.

Another class of artificial regulations involved using vague intuition to create a "rule" where there was not one before. An example of this was the condemnation of none used as a plural (e.g. "None of the answers are right"). The intuition here was that none was comprised of the words no + one. So it always had to be used in the singular (None of the answers is right). But none is not a combination of any words. It has always just been its own word and had been used in both the singular and plural by native speakers for hundreds of years without a second thought until pseudo-grammarians created the false distinction.

A fourth class of "rules" that pervade classrooms - and more problematically tests-represents a confusion of a tendency with a rule. In other words, there are some words that native speakers have a tendency to use in certain ways but do not always use in those ways - and are certainly not obligated to use in a certain way. In these cases pseudo-grammarians mistake a tendency for a rule. These conflations usually involve words with similar spellings, often words with the same root but different affixes. Here are some examples.

\subsection{Historic or Historical?}

Native speakers have a tendency to use historic for important events in history (Martin Luther King Jr. gave a historic speech) and historical when logging mundane facts about history (The historical average discrepancies between the rights of whites and blacks motivated King to his activism). This tendency is sometimes presented as a "rule" in EFL classrooms. But in reality native speakers often use the two interchangeably. Take the sentence, "The signing of the voting rights act was a truly event." Native speakers would tend to use historic in that sentence. But significant numbers would also use historical, which means that it is completely grammatical. This should be treated in EFL classrooms for what it is: a tendency-not a rule.

\subsection{Continuous(ly) or Continual(ly)?}

Native speakers have a tendency to use continuous(ly) for actions or phenomena that go on nonstop (It snowed continuously throughout the night-i.e. the snowfall never stopped) and continual(ly) when 
an action is completed and then repeated with gaps in between (The children continually asked questions throughout the class-i.e. children asked questions. Then there was a span of time where there were no questions, maybe while their questions were being addressed. And then more questions. Action-break-action.). Laypeople who confuse tendency with rule often lay this distinction down as law in the classroom when in reality native speakers very often use the two interchangeably.

\subsection{Farther or Further?}

Another tendency that pedants often cite as a "rule" is that farther can only be used for distance and further for extension of ideas or thoughts. According to this way of thinking, it's "We need to go a little farther down the road" and "Let's think further about this." False grammarians would cry violation were someone to say, "We need to go a little further down the road." Native speakers, however, used farther and further interchangeably when speaking about distance for hundreds of years-again with no interlocutorial befuddlement or contemporary castigation-until pseudogrammarians created the false farther/further distinction for distance. A prime example of the interchangeability of these two words is seen in an excerpt from a book on world languages by Stanford University linguistics professor, Asya Pereltsvaig: “...Chinese historical records show that Tai-Kadai used to live further [emphasis added] north than they are found now... This theory is further [emphasis added] confirmed by the fact that the diversity of the Tai-Kadai languages reaches its highest degree in south-eastern China." (Pereltsvaig 2017) Here Pereltsvaig uses further first for distance and then again in the same sentence for ideational extension. Needless to say, the discourse of a highly educated, articulate professor whose specific area of study is language is the gold standard of proper English rather than the fulminations of pseudo-grammarians with no training in the field.

\subsection{False Grammar Rule Honorable Mentions}

Honorable mentions go to two other tendencies sometimes laid down as rules: 1) Made from vs. made of. Made from is supposed to be used when the essence of the component parts changes substantively (wine is made from grapes); and made of is supposedly used when the essence does not change substantively (the chair is made of wood). 2) Choose between vs. choose among. Choose between is purportedly for when there are only two choices and choose among is for when there are more than two. Of course native speakers hear nothing strange when someone says, "You can choose between chocolate, strawberry, and vanilla." These, too, are tendencies incorrectly laid down as rules. Unfortunately, I have seen both tested as rules on grammar tests in Japan and South Korea.

\subsection{Lay or Lie?}

Finally, the second to the last sentence of the previous paragraph brings me to two words which arguably elicit the greatest outrage amongst the laity: lay and lie. I have met more than one person who, upon finding out what I do, has said something to the effect of: if you don't teach those people over there anything else about English, make sure you teach them how to use lay and lie correctly. Unfortunately for these sticklers, lay (to place something) and lie (to be in a recumbent position) were to a very great extent interchangeable amongst native speakers of English (OED 2019), with no danger of miscommunication or risk of fulmination from the grammar police until the height of the prescriptive craze in the $17^{\text {th }}$ and $18^{\text {th }}$ centuries. An utterly correct utterance in English that passes without comment amongst scholars of language but arouses gnashing of teeth and rending of garments amongst the grammatical laity is, "I'm going to lay down for a nap." Again, the laity has it wrong. The lay/lie distinction for spoken and informal written language is, simply, false.

In sum, an assumption, intuition, or pet peeve does not a grammar rule make. I have a whole host of personal pet peeves which grate on me like fingernails on a chalkboard. I grate my teeth when I hear reflexive pronouns used in grammatical contexts traditionally populated by personal pronouns. ("Why don't you join John, Sally, and myself at the party tonight?" Or, "I know this doesn't apply to people like yourself, who already eat healthy, organic food...") Traditionally these would have been "Why don't you come join John, Sally, and me; and I know this doesn't apply to people like you. But reflexive pronouns have expanded their domain. I hate it. But just because I don't like it doesn't mean there is a thing "wrong" with it, however much it personally vexes me. I also lament the loss of fewer to quantify countable nouns. Less has now almost universally displaced it so that even at the highest levels of formal and academic discourse utterances like "less jobs for less people" and "less cars on the road" are ubiquitous. Languages change. That is just the way it is. There is nothing ungrammatical 
at all in these utterances. They just do not agree with my own personal tastes. But, as must always be remembered, pet peeves do not grammar rules make.

\section{IMPLICATIONS FOR LEARNERS}

What are some of the implications for learners of these and other myths and misconceptions being propagated in EFL classrooms? The most obvious is that learners are not only burdened with having to memorize false grammar rules, but that valuable class time and time spent outside of class practicing the language is wasted with these bogus rules. Another downside is the unnecessary stress learners have to experience in trying to avoid these "errors."

But, as mentioned previously, the most pernicious situation is when tests that students take demand answers that accord with the bogus rules. The effects of students getting "wrong" answers on questions testing bogus rules range from the mildly annoying (getting a point off on a weekly quiz) to the potentially life-changing, as can happen when a single "mistake" on a question about something like lay/lie on a national university entrance test, such as those in countries like Japan and South Korea, can, in the hyper-competitive race to get into the top-ranked universities, mean not getting into the university a student had hoped to enter. These are just a couple reasons why educators should not be part of the problem by propagating these fallacies in the classroom and instead should become part of the solution by educating their students about what real language actually looks like.

\section{FREQUENTLY ASKED QUESTIONS}

I will conclude with some frequently asked questions about conducting EFL classes according to the scholarship of professional linguists and scholars of language rather than using the "rules," false as they may be, that have come to dominate the discourse of the laity.

\subsection{FAQ: Language will Disintegrate into Chaos if we Don't Guard Against Errors}

False. Discourse communities are systems in which an equilibrium naturally, and always, prevails. Language never changes fast enough for communication to disintegrate and make living native speakers unintelligible to one another. Complaints about not being able to understand "a single word" young people say these days are utterly unfounded. What actually is happening is that older generations are not parley to a very small lexical set of young users' vocabulary. In actuality they understand $99.99 \%$ of what other native speakers say. Further, it takes native speakers virtually no time and effort to understand new lexical items once they are explained. One native English speaker complained to me that she didn't understand what bling was. I explained it in under a minute and she was on her way in under a minute with a new item of vocabulary perfectly mastered. Old English is unintelligible to most speakers of modern English, but modern English is not a chaos of errors. It is a simple evolution of the language that at no point experienced debilitating communication failures amongst native speakers. Language changes. It does not degenerate or become a morass. And it does not change fast enough to make living native speakers unable to understand each other in a substantive way.

\subsection{FAQ: These Rules may be False, but if we don't Follow them in our Classrooms, our Students will not be Prepared for Standardized Tests such as the TOEFL.}

This is a legitimate fear amongst language teachers and the solution is to inform students that standardized tests test formal language and that on those tests, students must answer according to the prescriptivist "rules" they have grown up learning. When students are applying for programs of study, writing cover letters and resumes, having interviews with potential employers, etc., they still must follow the stylistic conventions of "standard" English. But the more who know the truth about language dynamism, the greater chance the truth will come to prevail someday. (For a worksheet I use with undergraduates in South Korea to introduce them to this issue, see appendices A and B.)

\subsection{FAQ: We shouldn't Base Standards of Good English on Figures Like Shakespeare. Aren't they "Just Artists" who "Take Liberties" with the Language?}

On the contrary. Great writers take the language to new heights, heights to which the rest of us should aspire. Those heights and the writers who take us there are the true standard bearers of English - not the prescriptions and proscriptions of prescriptivists with no training in and little knowledge of how language works. 


\subsection{FAQ: If English is Allowed to Diversify Naturally, isn't that a Disservice to Our Students? Won't it make it Harder for them to Learn if the Rules are Changing All the Time?}

This is a valid concern. But just because language learners are not native speakers, it doesn't mean they're incapable of coping with novelty or unable to learn new things about the language they are studying. Acquiring the latest slang is often not substantially different for a language learner than acquiring a new item of "standard" language that they have not encountered before. In fact, the real disservice to our students would be locking them into language which native speakers have moved on from. (Worse still would be accusations by educators that native speakers are "wrong" and making "errors" in their own language, and that students should steadfastly stay frozen in bygone ways of speaking.) Language dynamism must be incorporated into, or at least accepted by, language curricula if we are to prepare our students for communication in the actual discourse communities of the languages they are studying.

\subsection{FAQ: What is a Native Speaker?}

One question that comes more from the linguistic community than from the laity is that if your definition of correct grammar is whatever is uttered by a native speaker, what is a native speaker? Is someone from Singapore a native speaker? The Philippines? India? Is someone who came into a language community right on the cusp of the critical period for language acquisition, who speaks with perfect native speaker pronunciation, and is privy to all cultural references and other components which comprise native language competence, but on very rare occasions and with perfect native speaker pronunciation makes a mistake with noun verb agreement a native speaker? This is absolutely a legitimate issue and the discussion of the topic in academic linguistics is both warranted and welcome. But, it has no bearing on the thesis of this paper because, to paraphrase former United States Supreme Court Justice Potter Stewart, native speakers know native speakers when they hear them. And that is an absolutely valid definition of a native speaker when it comes to evaluating informal spoken and written discourse.

\section{CONCLUSION}

While the controversy over what if any role the explicit teaching of grammar should have in the EFL classroom is much discussed in the literature on pedagogy, this paper has discussed the legitimacy of the grammar "rules" themselves which constitute standards of accuracy to which second-language learners are held. It has recapped the evidence that many of those supposed rules are holdovers from arbitrary and specious claims from the era of the prescriptivist craze in the English language. Further, it has asserted that enforcing these bogus rules is not just a minor peccadillo but can have deleterious real-world implications for learners ranging from undue stress and wasted time in their studies to negative impacts on their futures when these "rules" appear on high-stakes tests.

It has also dispelled a number of common myths about purported negative implications if prescriptivist doctrine is not adhered to in the classroom, including that language standards will go down or that language will descend into an unintelligible chaos if these "rules" are not strictly enforced, and that English-language learners might be harmed in their preparations for standardized proficiency tests like the TOEFL, showing that all of these objections are without merit. But while it has shown the illegitimacy of bogus "grammar rules" for informal, spoken discourse, it has sided with Pinker in acknowledging the need for high standards in formal and written discourse.

\section{REFERENCES}

[1] Aitchison. J. (2013). Language change: Progress or decay? (4 ${ }^{\text {th }}$ ed.). Cambridge, UK: Cambridge University Press.

[2] Algeo, J. \& Butcher, C. (2013). The Origins and Development of the English Language. ( $7^{\text {th }}$ ed.) Belmont, CA. Wadsworth Publishing.

[3] Bohn, W.E. (1907). The development of John Dryden's literary criticism. PMLA, 22:1, 56-139. Retrieved from https://www.jstor.org/stable/456662

[4] Canale, M., \& Swain, M. (1980). A theoretical framework for communicative competence. Applied Linguistics, 1: 1-47.

[5] O'Connor, P. (2010). Origins of the specious: Myths and misconceptions of the English language

[6] Crystal, D. (2006). The fight for English: How language pundits ate, shot, and left. New York, NY: Oxford University Press. 
[7] Crystal, D. (2004). The stories of English. New York, NY: Oxford University Press.

[8] Crystal, D. (2007). Words, words, words. Oxford, UK: Oxford University Press.

[9] Davies, W. \& Langer, N. (2006). The making of bad language: Lay linguistic stigmatisations in German, past and present. Bern, Switzerland. Peter Lang Publishing.

[10] Ellis, R. (2005). Principles of Instructed Language Learning. Asian EFL Journal, 7:3, 1-16.

[11] Ellis, R. (2003). Task-based language learning and teaching. New York, NY: Oxford.

[12] Hitchings, H. (2011). The language wars: A history of proper English. New York, NY: Parrar, Straus and Giroux.

[13] Krashen, S. (1982). Principles and practice in second language acquisition. New York: Pergamon Press.

[14] Lightbown, P. \& Spada, N. (2013). How languages are learned (Oxford handbooks for language teachers) (4th ed.). Oxford, UK. Oxford University Press.

[15] McWhorter, J. (2017). Talking back, talking black: Truths about America's lingua franca. New York, NY: Bellevue Literary Press.

[16] McWhorter, J. (2011). What language is (and what it isn't and what it could be). New York, NY: Penguin.

[17] McWhorter, J. (1998). Word on the street: Debunking the myth of a "pure" standard English. New York, NY: Basic Books.

[18] McWhorter, J. (2017). Words on the move : why English won't - and can't - sit still (like, literally). New York, NY: Henry Holt and Co.

[19] Nation. P. (2001). Learning vocabulary in another language. New York, NY: Cambridge University Press.

[20] OED Online. March 2019. Oxford University Press. http://www.oed.com/viewdictionaryentry/Entry/111 25 (accessed May 19, 2019)

[21] Pereltsvaig. A. (2017). Languages of the world: An introduction. Cambridge: Cambridge University Press.

[22] Pienemann, M. (1989). Is language teachable? Psycholinguistic experiments and hypotheses. Applied Linguistics, 10, 52-79.

[23] Pienemann, M. \& and Lenzing, A. (2015). Processability theory. In B. VanPatten, B. and Williams, J. eds., Theories in second language acquisition. An introduction ( $2^{\text {nd }}$ ed.). New York, NY: Routledge.

[24] Pienemann, M. (2012). Processability theory and teachability. In Carol A. Chapelle ed., The encyclopedia of applied linguistics. Hoboken, NJ: Wiley-Blackwell.

[25] Pinker, S. (2014). The sense of style: The thinking person's guide to writing in the $21^{\text {st }}$ century. Oxford: Oxford University Press.

[26] Wolfram, W. \& Waldorf, K. (2019). Talking black in America: The role of the documentary in public education. English Today 35:1, 3-13.

\section{APPENDIX A}

Worksheet about grammar fallacies for undergraduates in South Korea

\section{Some points about grammar}

A. Read the following sentences. Do you think the grammar is correct $(O)$ or is there a grammar error $(X)$ ?

1. Jim is the person that gave me the money.

2. She is smarter than me.

3. Annette has the same hairstyle as me.

4. Is that him?

5. Everyone please pick up their pen.

6. Each person should have all the food they need.

7. None of the answers are right.

8. You have to choose between vanilla and chocolate.

9. You have to choose between vanilla, chocolate, and strawberry.

10. We need to go 10 kilometers further along the road.

11. I'm going to lay down for a nap. 


\section{B. Let's have a closer look at the sentences from part $A$.}

1) An anonymous 1752 essay condemned referring to people with the pronoun, "that." It would say the correct answer is "He is the person who took the money." This eventually became a grammar "rule." But native speakers of English had been using "that" to refer to people for hundreds of years. Nobody ever thought it was strange. This is a fake grammar rule. Wrong!

2) Robert Lowth (1710-1787), Lord Bishop of London, condemned this. He said that only I/he/she/we/them should follow the "be" verb. So according to him, the correct answer would be, "She is smarter than I." He said that the reason for this is that English came from Latin. And in Latin, the grammar works that way. Unfortunately for Bishop Lowth, there is one big problem with that. English did not come from Latin. English and Latin are related, but English is a Germanic language, not a "Latin" language. Lowth was a man of the church — not a scholar of English. So Lowth was just plain wrong.

3) Similar to \#2. Wrong again, Bishop Lowth.

4) Again, Lowth said that me/him/her cannot follow the "be" verb because me/him/her cannot do that in Latin. Wrong again, Bishop Lowth.

5) An American teacher, Anne Fisher (1719-1798) and others said that we should use the masculine pronouns, he/his/him, to refer to mixed gender groups. So she would say that the correct answer would be "Everyone pick up his pen." Again, she was not a scholar of the history of English and did not know that native speakers of English had been saying things like "Everyone pick up their pen" for hundreds of years. And nobody ever thought it was strange. So she (and others) simply created an artificial rule. Sorry, Ms. Fisher. You're wrong. It's sad, too, that a woman was advocating this "rule."

6) Same as \#5. Wrong again, Ms. Fisher.

7) Lindley Murray (1745-1826) was an American lawyer whose hobby was writing about grammar. He said that "none" was a combination of "no" plus "one." So it should be used like "one." It should be singular - not plural. He would say that the correct answer is "None of the answers is right." But this is wrong. "None" has always just been its own word. Murray wrote about grammar as a hobby, not as a scholar. This is a false rule. Sorry, Mr. Murray. Wrong!

8-9) Both are correct. It is not clear who invented the "rule" that between is supposed used for two things and among is to be used for more than two things. But it is a false rule. Between can often be used to talk about more than two things.

10) Native speakers of English had been using farther and further for distance interchangeably for hundreds of years. And nobody ever thought it was strange. Only recently have grammar "experts" created a difference. They say that farther should be used for physical distance and further should be used for figurative distance. So they would say that the correct answer would be "Let's walk a little farther along the street" (and "Let's think further about this."). This is another fake rule.

11) Native speakers of English had been using "lay" and "lie" completely interchangeably for hundreds of years. Great writers like Shakespeare had, too. And nobody ever thought it was strange. Only recently have grammar "experts" created a difference. They say that "lay" requires a direct object and "lie" does not. So they would say that the correct answer would be "I'm going to lie down for a nap" (and "Please lay the piece of paper on the table."). This is yet another bogus rule.

Some terms:

--language mistake: I'm a normal a _ _ lt $\mathrm{n}_{-} \mathrm{t}$ _ ve-speaker, but I was speaking too $\mathrm{f}_{-}$st or something and just made a small mistake, a slip of the tongue.

--grammar error: I d _ ' $\mathrm{d}_{-} \mathrm{k}_{-} \mathrm{W}$ what is correct because I am a ch ${ }_{-} \mathrm{d}_{\text {under }}$ the age of about 6 , or a $\mathrm{n}_{-} \mathrm{n}-\mathrm{n}_{-} \mathrm{t}_{-}$ve speaker.

C. How about these? Answer true (T) or false (F) for the following: rules.

1. Many of the grammar rules you learned in textbooks about English are not real grammar

2. Regular people make grammar errors in their native language. Only "grammar experts" know the correct grammar. 
3. Shakespeare was a great writer, but he sometimes made grammar errors in his plays and poems.

4. The grammar of regular people and great writers like Shakespeare is right. "Experts" can't criticize their grammar.

5. As an adult, former U.S. president, George W. Bush made grammar errors in English.

6. As an adult, South Korean poet, Kim Hye Soon made grammar errors in Korean.

7. As adults, native speakers sometimes make grammar errors in their own native language.

8. Correct grammar is what native speakers do naturally-not what "grammar experts" say people should do.

9. If a normal, adult native speaker says it, it is correct. "Grammar experts" are not more correct than regular people.

10. Some native speakers have a more elegant style than others. But all adult native speakers have correct grammar.

11. For 선릉역, regular people often pronounce 선릉 like 성능 or 선능. But they are wrong. Only 설릉 is correct.

12. In 선릉역, 선릉 can be pronounced 성능/선능 or 설릉. All are correct. (But maybe 설릉 is more elegant in style.)

13. Language is the ultimate democracy. Normal, adult native speakers speaking their own languages always have correct grammar. No normal, adult native speaker has "more correct" grammar than any other normal, adult native speaker.

"One of the most frustrating things for any linguist is a virtually universal misimpression that the world is full of people [making grammar errors in their native languages, one of the] myths about language dismissed by all linguists, but [believed by] almost everyone else." -Columbia University linguistics professor, John McWhorter

\section{APPENDIX B}

The worksheet in Appendix A with answers

\section{Some points about grammar}

A. Read the following sentences. Do you think the grammar is correct $(O)$ or is there a grammar $\operatorname{error}(X)$ ?

_ $\mathrm{O} \_$_ $1 . \mathrm{Jim}$ is the person that gave me the money.

O__ 2. She is smarter than me.

O__ 3. Annette has the same hairstyle as me.

O__ 4. Is that him?

O__ 5. Everyone please pick up their pen.

O_ _ 6. Each person should have all the food they need.

O__ 7. None of the answers are right.

O__ 8. You have to choose between vanilla and chocolate.

O__ 9. You have to choose between vanilla, chocolate, and strawberry.

O__ 10. We need to go 10 kilometers further along the road.

O__ 11. I'm going to lay down for a nap.

$\boldsymbol{B}$. Let's have a closer look at the sentences from part $A$.

1) An anonymous 1752 essay condemned referring to people with the pronoun, "that." It would say the correct answer is "He is the person who took the money." This eventually became a grammar 
"rule." But native speakers of English had been using "that" to refer to people for hundreds of years. Nobody ever thought it was strange. This is a fake grammar rule. Wrong!

2) Robert Lowth (1710-1787), Lord Bishop of London, condemned this. He said that only I/he/she/we/them should follow the "be" verb. So according to him, the correct answer would be, "She is smarter than I." He said that the reason for this is that English came from Latin. And in Latin, the grammar works that way. Unfortunately for Bishop Lowth, there is one big problem with that. English did not come from Latin. English and Latin are related, but English is a Germanic language, not a "Latin" language. Lowth was a man of the church — not a scholar of English. So Lowth was just plain wrong.

3) Similar to \#2. Wrong again, Bishop Lowth.

4) Again, Lowth said that me/him/her cannot follow the "be" verb because me/him/her cannot do that in Latin. Wrong again, Bishop Lowth.

5) An American teacher, Anne Fisher (1719-1798) and others said that we should use the masculine pronouns, he/his/him, to refer to mixed gender groups. So she would say that the correct answer would be "Everyone pick up his pen." Again, she was not a scholar of the history of English and did not know that native speakers of English had been saying things like "Everyone pick up their pen" for hundreds of years. And nobody ever thought it was strange. So she (and others) simply created an artificial rule. Sorry, Ms. Fisher. You're wrong. It's sad, too, that a woman was advocating this "rule."

6) Same as \#5. Wrong again, Ms. Fisher.

7) Lindley Murray (1745-1826) was an American lawyer whose hobby was writing about grammar. He said that "none" was a combination of "no" plus "one." So it should be used like "one." It should be singular - not plural. He would say that the correct answer is "None of the answers is right." But this is wrong. "None" has always just been its own word. Murray wrote about grammar as a hobby, not as a scholar. This is a false rule. Sorry, Mr. Murray. Wrong!

8-9) Both are correct. It is not clear who invented the "rule" that between is supposed used for two things and among is to be used for more than two things. But it is a false rule. Between can often be used to talk about more than two things.

10) Native speakers of English had been using farther and further for distance interchangeably for hundreds of years. And nobody ever thought it was strange. Only recently have grammar "experts" created a difference. They say that farther should be used for physical distance and further should be used for figurative distance. So they would say that the correct answer would be "Let's walk a little farther along the street" (and "Let's think further about this."). This is another fake rule.

11) Native speakers of English had been using "lay" and "lie" completely interchangeably for hundreds of years. Great writers like Shakespeare had, too. And nobody ever thought it was strange. Only recently have grammar "experts" created a difference. They say that "lay" requires a direct object and "lie" does not. So they would say that the correct answer would be "I'm going to lie down for a nap" (and "Please lay the piece of paper on the table."). This is yet another bogus rule.

\section{Some terms:}

--language mistake: I'm a normal adult native speaker, but I was speaking too fast or something and just made a small mistake, a slip of the tongue.

--grammar error: I don't know what is correct because I am a child under the age of about 6 , or a non-native speaker.

C. How about these? Answer true (T) or false ( $F)$ for the following:

$\mathrm{T}$ _ 1. Many of the grammar rules you learned in textbooks about English are not real grammar rules.

F__ 2. Regular people don't always speak with correct grammar in their own native language. Only "grammar experts" know the correct grammar.

F__ 3. Shakespeare was a great writer, but he sometimes made grammar errors in his plays and poems. 
T_ 4. The grammar of regular people and great writers like Shakespeare is right. "Experts" can't criticize their grammar.

F___ 5. As an adult, former U.S. president, George W. Bush made grammar errors in English.

_ F__ 6. As an adult, South Korean poet, Kim Hye Soon made grammar errors in Korean.

_F__ 7. As adults, native speakers sometimes make grammar errors in their own native language.

T_ 8. Correct grammar is what native speakers do naturally—not what "grammar experts" say people should do.

T_ 9. If a normal, adult native speaker says it, it is correct. "Grammar experts" are not more correct than regular people.

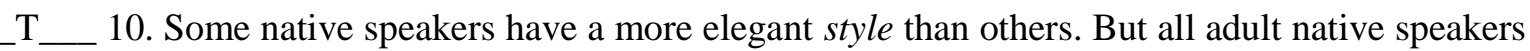
have correct grammar.

_ F _ _ 11. For 선릉역, regular people often pronounce 선릉 like 성능 or 선능. But they are wrong. Only 설릉 is correct.

드느 12. In 선릉역, 선릉 can be pronounced 성능/선능 or 설릉. All are correct. (But maybe 설릉 is more elegant in style.)

$\mathrm{T}$ _ 13. Language is the ultimate democracy. Normal, adult native speakers speaking their own languages always have correct grammar. No normal, adult native speaker has "more correct" grammar than any other normal, adult native speaker.

"One of the most frustrating things for any linguist is a virtually universal misimpression that the world is full of people [making grammar errors in their native languages, one of the] myths about language dismissed by all linguists, but [believed by] almost everyone else." -Columbia University linguistics professor, John McWhorter

Citation: Todd Hull. Grammar: How not to be Part of the Problem. "International Journal on Studies in English Language and Literature (IJSELL),vol 7, no. 8, 2019, pp. 14-25. doi: http://dx.doi.org/10.20431/23473134. 0708002.

Copyright: () 2019 Authors. This is an open-access article distributed under the terms of the Creative Commons Attribution License, which permits unrestricted use, distribution, and reproduction in any medium, provided the original author and source are credited. 